\title{
BACKGROUND OF HUMAN CAPITAL DEVELOPMENT IN THE CONTEXT OF FORMING THE ECONOMY OF KNOWLEDGE
}

\author{
Tetiana Iankovets \\ Department of Entrepreneurship and Business \\ Kyiv National University of Technologies and Design \\ 2 Nemyrovycha-Danchenka str., Kyiv, Ukraine, 01011 \\ tanyayankovec@ukr.net
}

\begin{abstract}
The general definition of human capital has been given, the most important factors of influence on it regardless of the hierarchical level of the economic system, namely education and health, have been indicated in the article.

The stages of the human capital development from the basic to the innovative one have been identified and the important internal human factors that can be influenced from the outside, reinforcing them, which will influence the increase of the level of human capital have been emphasized.

The Global Human Capital Report of the World Economic Forum in 2017 has been analyzed in order to identify the place of Ukraine and its determinants, as compared to countries, the highest level of human capital in the world. This allowed identifying the problems of human capital development in Ukraine and the corresponding directions of their overcoming. The main problems include: lowering the welfare and quality of life of the population; departure of highly skilled specialists abroad; the reduction of employment opportunities in the specialty due to the low qualification and inconsistency of the received education with the demanded occupations in the labor market, which are changing on a global scale. To overcome these problems, it is important to create certain preconditions at different hierarchical levels of the economic system in the context of the knowledge economy formation. At macro level, the prerequisites for the human capital development include: implementation of measures to overcome corruption; the revival of morality and the general culture of society; creation of a favorable innovation climate and an innovative culture of the country's population; maintenance of domestic commodity producers; development and implementation of effective intellectual property rights protection instruments at the legislative level. On the meso-level, such preconditions are: the development of higher and special vocational education in the branch directions; development of innovation infrastructure; distribution of clusters for business development; the maintenance of domestic commodity producers. At micro level, the above-mentioned prerequisites include: scientific approach to the organization of work; modern quality and efficient management system and relevant organizational structure and system of labor motivation and stimulation; introduction of innovative approaches, methods, tools in all areas of activity.

Keywords: economy of knowledge, human capital, human capital development, entrepreneurship, human capital development stages, innovative human capital.
\end{abstract}

\section{Introduction}

In a post-industrial society which is identified as a "knowledge society", services that are designed to meet the ever-more diverse needs of people and society become the main value. This requires the change of technology to the scientific and intellectual, key productive resources for which are information and knowledge [1, p. 84]. Such transformation implies an increase in the role of human capital and innovation in the formation of knowledge economy, which is closely and inseparably linked with entrepreneurial initiative [2, p.137].

The founder of the human capital theory is Theodore Schultz, an American scholar, economist, professor at the University of Chicago, who first used the phrase "human capital" [3]. In his studies on the example of America, and rapid recovery in post-war Japan and Germany, he proved that the prosperity of the state is not based on the real capital (minerals, banks richness), and the human capital (educated and healthy people in the country) [4]. From these studies the "theory of human capital" started, which received international recognition, as evidenced by the award of the 1979 Nobel Prize in Economics for "pioneering research of economic structure of developing countries".

The most productive follower of T. Schulz was Gary Stanley Becker, who in his writings "Investing in human capital: theoretical analysis" (1962) [5] and "Human capital: theoretical and em- 
pirical analysis with a special emphasis on education" (1993) [6] gave a holistic scheme and explained human behavior from an economic point of view. The scientist argued that investing in human capital is more profitable than investing in securities. Becker was the first to make a statistically correct calculation of the investment in education efficiency. For his research results in 1992, he received the Nobel Prize in Economic Sciences "for having extended the domain of microeconomic analysis to a wide range of human behaviour and interaction, including nonmarket behaviour".

The following scientists have made a significant contribution to the formation of the human capital theory in modern science: O. Grishnova has thoroughly investigated problems of the human capital formation and development at various hierarchical levels of economic system and determined the factors of its growth at these levels; has substantiated the interconnection of human capital with intellectual and social capital, proposed approaches to evaluation; has identified ways to preserve human capital in a crisis [7, 8]; N. Azmiuk has discovered the factors of formation and development the human capital innovative forms [9]; V. Kovalchuk has defined human capital as a powerful factor in the innovation development of economy and proposed an organizational and economic mechanism for investing in human capital in the context of globalization processes intensification [10]; O. Mazina has proposed an approach to assessing the value of human capital taking into account the risks of its dissipation and the possibilities of its preservation and development [11]; O. Levchenko, D. Plynokos, O. Tkachuk have made suggestions on the main directions of innovative influence on the processes of human capital formation and development in Ukraine [12]; A. Osiychuk has highlighted the role of the institutional system in the human capital formation and development [13].

Human capital is closely connected with socio-economic development and is one of the determinants of such development in the works of modern scientists. At the same time, the problems of human capital development in the modern conditions of knowledge economy formation, which is possible in case of creating certain prerequisites at different hierarchical levels of the economic system, are still unresolved.

\section{Aim of research}

Determine the preconditions for the human capital development in the context of knowledge economy formation.

\section{Research methods}

The research is based on the use of the system approach basic provisions. To solve the problem of determining the preconditions for the development of human capital in the conditions of knowledge economy formation, general scientific and special methods of processes and phenomena research in their interconnection and development are used, namely:

- dialectic, analysis and synthesis, induction and deduction;

- system-structural analysis (with allocation of factors of influence on human capital);

- structural-logical analysis (in identifying the stages of human capital development);

- comparative analysis (comparing Ukraine's ranking with other countries and identifying problems of human capital development);

- logical generalization (in determining the preconditions for the development of human capital in modern conditions).

\section{Results}

In general, human capital, regardless of the economic system hierarchical level, is understood as a result of investment and a certain stock of health, knowledge, skills, abilities and other productive qualities accumulated by people, formed or developed, which, under the influence of external and internal factors, are purposefully used to create added value, income growth, welfare and quality of life.

Factors influencing the development of human capital are divided into internal in relation to a person, caused by a person himself, and external ones (conditions of development) $[9$, p. $48 ; 11$, p. 17]. 
The most important factors, starting with the studies of classics and resuming with the conclusions of modern scholars, include the level of people's education and health. Moreover, these factors are considered both internal and external. Modern researchers make a decisive emphasis on education. So, O. M. Levchenko, D. D. Plinokos, O. V. Tkachuk under the conditions of innovative development (which is at the same time a prerequisite and result of the knowledge economy formation - author's note), distinguish education as the most important factor influencing the formation of human capital and, accordingly, economic development and GDP, two thirds of which are created in the world due to human capital $[12$, p. 6]. N. Azmuk argues that high education contributes to the increase of labor productivity and higher individual income, which, in turn, leads to an increase in consumer spending and market demand, an incentive for development and, as a result, accelerates economic growth [9, p. 49]. For advanced economies, this thesis is confirmed by the results of a study by the World Economic Forum [14] published in the Global Human Capital Report, 2017. In this study, human capital incorporates the knowledge and skills of people, which makes it possible to create value in the global economic system. We emphasize that the knowledge and skills that a person owns cannot be considered as capital, if their implementation does not create value. This principle extends to other hierarchical levels of the economic system (from the global to the individual entity level).

That is, human capital exists only if human labor is applied in the socio-economic conditions (at the level of the enterprise, industry, region, country, global economy) and the creation of its added value and, accordingly, the receipt of income as a carrier of human capital (in the form of wages for hired workers or income for entrepreneurs to do their own business) and the enterprise, region, country, world (GDP growth, GNP, national wealth, welfare and quality of life).

The Global Human Capital Index 2017 assesses human capital globally in four areas from which we identified the stages of human capital development (Table 1).

Table 1

Evaluation criteria and stages of human capital development

\begin{tabular}{|c|c|c|}
\hline Evaluation criterion & Explanation & Stages of human capital development \\
\hline Capacity & $\begin{array}{l}\text { The level of formal education for younger and older } \\
\text { generations as a result of past investment in education }\end{array}$ & Getting education, basic knowledge \\
\hline Deployment & $\begin{array}{l}\text { Applying qualifications and skills accumulating } \\
\text { among adults }\end{array}$ & $\begin{array}{l}\text { Accumulating knowledge in the process of } \\
\text { work, knowledge and skills consolidation }\end{array}$ \\
\hline Development & $\begin{array}{l}\text { Formal education of the new generation of labor force } \\
\text { and continuing education through advanced training and } \\
\text { retraining of the current workforce }\end{array}$ & $\begin{array}{c}\text { Experience, maturity, continuous } \\
\text { improvement }\end{array}$ \\
\hline Know-how & Width and depth of using special skills in work & $\begin{array}{l}\text { New higher quality of knowledge and skills, } \\
\text { creativity, new opportunities for applying } \\
\text { knowledge, higher innovative thinking, } \\
\text { innovative human capital }\end{array}$ \\
\hline
\end{tabular}

Source: systematized by the author on the basis of [14]

It should be noted that for the gradual creation of higher, innovative thinking, the highest innovative level of human capital, we need the following: strong internal motivation, high responsibility, discipline, constant self-improvement through self-regulation, self-organization, self-education (the application of system principles of human being as a carrier of human capital), and high spirituality. These are internal factors of human capital development, which may also be influenced by external stimuli.

The Global Human Capital Index 2017 estimates 130 countries according to how they develop human capital in their countries (Table 2).

In general, according to the World Economic Forum, only $62 \%$ of the world's human capital is currently developing [14]. The greatest productivity of human capital in the world occurs in such countries as the USA, Germany, Canada, Russia and Japan. Among the European countries with the highest productivity, human capital is used in Finland, Denmark, Sweden, Germany, Slovenia 
and Estonia. The main factors contributing to this include: high quality education; employment of older generation specialists in highly qualified professions; qualitative systems of vocational education and training of the personnel.

Table 2

The ranking of countries according to the Global Human Capital Index 2017

\begin{tabular}{|c|c|c|c|}
\hline Country & $\begin{array}{l}\text { Global Human } \\
\text { Capital Index }\end{array}$ & $\begin{array}{l}\text { Rank- } \\
\text { ing }\end{array}$ & Characteristics \\
\hline Norway & 77.12 & 1 & $\begin{array}{l}\text { The most successful country in the world. Highly skilled workers are avail- } \\
\text { able. The lowest unemployment rate. }\end{array}$ \\
\hline Finland & 77.07 & 2 & $\begin{array}{l}\text { High level of elementary schools quality as well as the general education } \\
\text { system. High level and diversification of professional and higher education. } \\
\text { Employment of older generation professionals in highly qualified professions. } \\
\text { At the same time, the unemployment rate among young people is } 20 \% \text {. }\end{array}$ \\
\hline Switzerland & 76.48 & 3 & $\begin{array}{l}\text { High quality education system. However, a gender gap is kept both in the } \\
\text { working age and in the older generation. }\end{array}$ \\
\hline USA & 74.84 & 4 & $\begin{array}{l}\text { Developed education system, young people and older people study at universi- } \\
\text { ties, high level of graduates' competitiveness. Employment of older generation } \\
\text { professionals in highly qualified professions. Low unemployment. At the same } \\
\text { time, there is an uneven distribution and polarization of human capital (large } \\
\text { low-skilled sector). Low quality of elementary education. }\end{array}$ \\
\hline Denmark & 74.40 & 5 & High quality of education system. \\
\hline Germany & 74.30 & 6 & $\begin{array}{l}\text { Creative and innovative thinking of the workers, developed at the workplace } \\
\text { and in the process of advanced training and retraining. Highly educated older } \\
\text { generation. Aging population. }\end{array}$ \\
\hline New Zeland & 74.14 & 7 & High quality of education system. \\
\hline Sweden & 73.95 & 8 & $\begin{array}{l}\text { High quality of education system. Creative and innovative thinking of the } \\
\text { workers. }\end{array}$ \\
\hline Slovenia & 73.33 & 9 & Highly educated older generation. \\
\hline Austria & 73.29 & 10 & High quality professional education, great variety of graduates' skills. \\
\hline Singapore & 73.28 & 11 & $\begin{array}{l}\text { The second largest share of highly skilled labor in the world, high-quality } \\
\text { education and personnel training. Gender gap. }\end{array}$ \\
\hline Estonia & 73.13 & 12 & Creative and innovative thinking of the workers. \\
\hline$\cdots$ & $\cdots$ & $\cdots$ & - \\
\hline Ukraine & 71.27 & 24 & $\begin{array}{l}\text { The advantage to investing in higher education of younger generations. Emi- } \\
\text { gration of highly skilled specialists. }\end{array}$ \\
\hline
\end{tabular}

Source: formed by the author on the basis of [14]

In Ukraine, the rate of human capital development is more than $70 \%$, which is much higher than GDP per capita (USD 2185.83 at the official NBU rate [15]).

According to the global index of human development, Ukraine ranks 24 th in the World Economic Forum ranking, while the level of investment in education is 5th (index 81.70), by the level of accumulation and improvement of knowledge through advanced training and retraining - 31st place (index 72.65), the level of knowledge extend among adult population - 38th place (index 71.47) and the level of width and depth of special skills using in work also 38th place (index 59.26).

Almost $80 \%$ of population in Ukraine invests in their own higher education (to compare, only $50 \%$ of the population in Japan have higher education, $31 \%$ in the United States, only $10 \%$ and $8 \%$ in China and India respectively have higher education [14]). In the process of working in Ukraine, workers are mainly from 25 to 54 years of age undergoing advanced training and/or retraining in order to develop their own human capital. Employees of younger and early retirement age have less activity in this direction. Yet, according to the level of education and development of professional skills, according to the World Economic Forum, Ukraine has high rates and is close to such countries as Russia, Japan, Germany, and Kazakhstan. 
The problem in Ukraine, as well as in other developing countries, is the decline of employment opportunities in the specialty due to the low qualification and inconsistency of the received education with the demanded professions on the labor market, which are changing on a global scale.

Technological changes in the global world affect the transformation of labor markets, which involves changes in the human capital formation and its impact on the socio-economic development of countries, improving the well-being of the population and quality of its life. Today, the most popular among the specialties in the labor market are business administration, law, social sciences, and journalism, information, as well as information and communication technologies. The development of the latter has substantially accelerated today. Mature specialists are dominant in this field in such countries as Sweden, Australia, the United States, Switzerland, and the United Kingdom. Young specialists are predominant in Lithuania, Brazil, Romania, and Estonia. It is interesting that in the Global Human Capital Report 2017 among the LinkedIn (a social network for the search and establishment of business contacts, the information used to formulate the report, the research partner of the World Economic Forum) users, there are no partners from Ukraine. For example, when analyzing the skills of those who have information and communication technologies by age and country, there are no data concerning Ukraine. This shows that this direction of business contacts through the social network LinkedIn, popular in the world, is not used in our country, although it is well-known that Ukrainian IT professionals are in demand in other countries, which speeds up their emigration. Development of business contacts with foreign partners, in turn, is one of the areas of scientific and technical cooperation, generation of new ideas, and innovative development of human capital.

Knowledge, abilities, skills, creativity, tendency to perceive innovations, etc. as the basis of human capital, are the key factors of economic growth, for successful implementation of which the certain prerequisites are needed. In the contest knowledge economy formation, we include the following:

1) At the country level (macro level):

- implementation of measures to overcome corruption[16];

- the revival of morality and the general culture of society;

- creation of favorable innovative climate and innovative culture of the country's population;

- maintenance of domestic commodity producers;

- development and implementation of effective intellectual property rights protection instruments at the legislative level.

2) At the level of regions and types of economic activity (meso-level):

- development of higher and special professional education in the branch directions;

- development of innovative infrastructure;

- distribution of clusters for business development;

- maintenance of domestic commodity producers.

3) At the enterprise level (micro level):

- scientific approach to the organization of work;

- modern high-quality and efficient management system and appropriate organizational structure and system of motivation and stimulation of labor;

- introduction of innovative approaches, methods, tools in all areas of activity.

It should be noted that human capital is transformed into an innovative one in the context of continuous improvement of knowledge and skills in the process of labor, the cumulative number of which, under appropriate conditions, becomes a higher quality, which ensures the development of human capital on an innovative basis.

\section{Discussion}

The main scientific novelty of the research is the substantiation of the preconditions for human capital development at different hierarchical levels of the economic system (at the level of the country, at the level of the region or a separate type of economic activity and at the level of the individual economic entity - the enterprise). Unlike the classical historical, economic, political, social and other prerequisites for human capital development identified in modern science [9, 17], 
their distribution on the hierarchical levels of the economic system will allow in the future to study in detail the trends and substantiate the systemic measures of human capital development in the conditions of knowledge economy formation.

The scientific result also refers to the identification of the human capital development stages, which makes it possible to systematically approach its formation and implementation and bring it up to a higher innovative level. This made it possible to identify internal factors in human development of human capital. At the same time, this study does not propose ways to influence internal factors from the outside, which would justify measures aimed at developing and improving the efficiency of human capital use.

The problems of human capital development in Ukraine also discovered in this study need to be studied in more detail in order to solve them. For example, the creation of a comprehensive program for human capital development at all levels of the economic system by integrating and cooperating with state, regional, educational, scientific institutions, business, etc., is essential for preserving the existing human capital, which is a matter of national security in today's crisis conditions.

\section{Conclusions}

1. Getting education and basic knowledge, their accumulation in the process of work, consolidating knowledge and skills, gaining experience as well as the continuous improvement are the stages human capital development, which leads to a new higher quality of knowledge and skills, creativity, new possibilities of applying knowledge, higher innovative thinking, innovative human capital. Successful implementation of human capital development stages is possible due to the systematic process of continuous self-education, self-organization, self-regulation and self-improvement of people throughout life. On the side of the state, local authorities and business it is important to create conditions for the human capital development.

2. Ukraine has a rather high level of human capital development (24th in the world from 130 countries and $70 \%$ of use), mainly due to investments in its own first higher education ( $80 \%$ of the population)). At the same time, major problems are the reduction of employment opportunities in the specialty due to the low qualification and inconsistency of the obtained education with the demanded occupations in the labor market, which are changing on a global scale, as well as the mass emigration of qualified specialists to other countries in the conditions of economic and political crisis.

3. As the knowledge economy is closely linked to innovation and entrepreneurial initiative, the creation of the above-mentioned preconditions at all hierarchical levels of the economic system and the directions of human capital found in further research will form the basis for the development of an organizational and economic mechanism for human capital development on an innovative basis to increase the efficiency of entrepreneurial activity and, as a result, improving the well-being and quality of people's life.

\section{References}

[1] Kyvliuk, O. P., Sakun, A. V. (2017). Knowledge economyas an intellectual resourceof knowledge management theory. Scientific bulletin of Polissia, 2 (10 (1)), 83-89.

[2] Olshanska, O. V., Melnyk, A. O., Iankovets, T. M. (Eds.) (2016). Efficiency of activity of enterprises in the conditions of globalization processes. Kyiv: KNUTD, 390.

[3] Theodore William Schultz. The official website of the Simon Kuznets Kharkiv National University of Economics. Available at: http://www.hneu.edu.ua/Theodore_William_Schultz

[4] Schultz, T. (1971). Investment in Human Capital. The Role of Education and of Research. Vol. XII. New York: The Free Press, London: Collier-Macmillan Limited, 272.

[5] Becker, G. S. (1962). Investment in Human Capital: A Theoretical Analysis. Journal of Political Economy, 70 (5 (2)), 9-49. doi: 10.1086/258724

[6] Becker, G. S. (1993). Human Capital: A Theoretical and Empirical Analysis with Special Reference to Education. Chicago, London: The University of Chicago Press, 412. doi:10.7208/chicago/ 9780226041223.001.0001

[7] Hrishnova, O. A. (2014). Human, intellectual and social capital of Ukraine: essence, interconnection, estimation, directions of development. Social-labor relations: theory and practice, 1 (7), 34-42. 
[8] Grishnova, O., Dmitruk, S. (2015). Human capital under crisis: evaluation and preservation opportunities search. Bulletin of Taras Shevchenko National University of Kyiv Economics, 5 (170), 11-16. doi: 10.17721/1728-2667.2015/170-5/2

[9] Azmuk, N. (2014). The factors of formation and development of human capital innovative forms. Ukraine: aspects of labor, 3, 47-51.

[10] Kovalchuk, V., Shakhno, A. (2016). Investing in human capital as a factor of innovation development of Ukrainian economy. Socio-economic problems and the state, 2 (15), 33-40.

[11] Mazina, O. (2012). Estimation and factors of human capital development. State and economy. KNUTE Bulletin, 6, 16-26.

[12] Levchenko, O. M., Plynokos, D. D., Tkachuk, O. V. (2015). Human capital as a factor for the innovative development of the national economy of Ukraine. State and Regions, 5 (86), 3-9.

[13] Osiichuk, O. A. (2013). Human capital theory development. Bulletin of Khmelnytskyi National University, 3 (3), 138-142.

[14] The Global Human Capital Report 2017. (2017). World economic forum. Available at: https:// www.weforum.org/reports/the-global-human-capital-report-2017

[15] Official site of the National Bank of Ukraine. Available at: https://www.bank.gov.ua/

[16] Official site of the Transparency International (the global coalition against corruption). Available at: www.transparency.org/

[17] Mykhailova, L. I. (2008). Human Capital: Formation and Development in Rural Regions. Kyiv: Center for Educational Literature, 388.

\title{
ECONOMIC EFFICIENCY OF USING SOLAR ENERGY IN THE AGROINDUSTRIAL BUSINESS
}

\author{
Liudmyla Uniiat \\ Department of Accounting and Economics-Legal Providing of Agroindustrial Business \\ Ternopil National Economic University \\ 11 Lvivska str., Ternopil, Ukraine, 46020 \\ luda@uniyat.in.ua
}

\begin{abstract}
Under conditions of limited organic resources, polluted external environment, excessive emission of carbon in the atmosphere and as a result of global warming the use of renewed energy sources may become one of ways of solving problems of energy saving, energy efficiency, environment protection, energy independence from import raw materials. The active use of renewed energy sources will favor the increase of economic efficiency and competitiveness of components of the national AIC.

The article indicates that during the last 20 years the world underwent worsening of natural-climatic and living conditions, climate change, strengthening of negative natural phenomena and so on. The aforesaid problems of the world scale were discussed at the international climatic conferences (Brazil - 1992; Japan - 1997; SAR - 2002; Paris - 2015; Germany - 2017), while considering the complex of questions as to improving the natural-climatic and living environment in the world, saving use of natural resources, acceleration of using renewable energy sources (RES), especially solar one.

It was elucidated, that during the last years the power of solar energy stations (SPS) grew essentially. For the end of 2015 the leaders if setting SPS were the following countries: China, Germany, Japan, USA. In Ukraine the plan of development of the Combined energetic system for 2016-2025 years of SE «NEC «Ukrenergo»» provided the association of SPS power with electric nets of energy system with volume 1641.2 MW.

There was realized the grouping of Ukrainian regions by the level of the technically achievable potential of solar energy.

There was realized the assessment of the economic efficiency of products at using solar energy in the agroindustrial business in different regional conditions of Ukraine.
\end{abstract}

Keywords: solar energy, efficiency of projects, cash receipts, cash expenses, payback period, return on investments. 